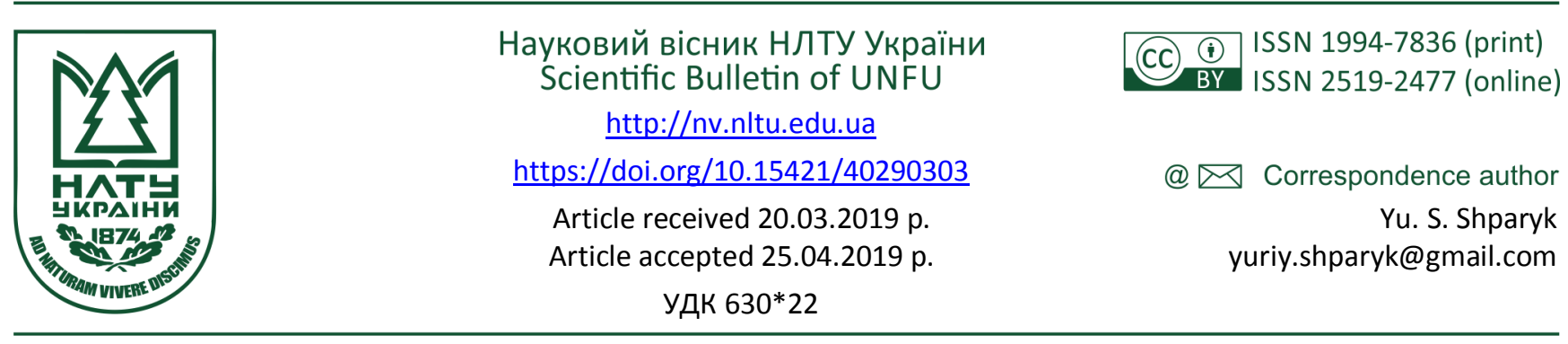

Ю. С. Шиарик

Український НДІ гірського лісівнищтва ім. П. С. Пастернака, м. Івано-Франківськ, Україна

\title{
ЕМПІРИЧНІ ПІДХОДИ ДО ПРОГНОЗУВАННЯ ПЛОЩІ ТА ЗАПАСУ ЯЛИНОВИХ (PICEA ABIES (L.) KARST.) ЛICIВ УКРАЇНСЬКИХ КАРПАТ
}

\begin{abstract}
Стаціонарні дослідження всихання ялинників Українських Карпат на 22-х постійних дослідних об'єктах дали можливість оцінити інтенсивність їх всихання за основними типами лісу, в яких ростуть ялинники. Запропоновано метод прогнозування площі ялинників регіону та запасів ялинової деревини за отриманими частками всихання. Для розробки прогнозу прийнято за базове ідентифіковане положення, що інтенсивність всихання ялинників визначається такими показниками деревостану в межах одного типу лісу, як: група віку, повнота, частка ялини в породному складі. Для розрахунку використано функцію екстраполяції існуючих тенденцій цих змін на не охоплені дослідженнями типи лісу і типи деревостанів за такими закономірностями: завдяки збільшенню вологості та родючості типів лісу інтенсивність всихання ялини зменшується; у несмерекових типах лісу інтенсивність всихання ялини більша, ніж у смерекових; у змішаних (не однопородних) типах лісу інтенсивність всихання ялини менша за чисті (однопородні) типи лісу; в типах лісу поза межами природного ареалу ялини інтенсивність її всихання найвища; всихання починається у середньовікових лісах і з віком його інтенсивність зростає; внаслідок зменшення повноти інтенсивність всихання зростає; завдяки зменшенню частки ялини в породному складі інтенсивність всихання знижується. За прогнозами всихання ялинників ДП "Надвірнянське лісове господарство" в умовах вологої буково-ялицевої сусмеречини видно, що впродовж 20 років втратиться $18 \%$ площі ялинників та майже 90 \% запасів ялинової деревини. Підготовлено пропозиції з відновлення площі ялинників регіону за типами лісу.

Ключові слова: ялина європейська (Picea abies (L.) Karst.); всихання; тип лісу; група віку; повнота; склад порід; лісові
\end{abstract} культури; рубки догляду.

Вступ. Всихання ялинників Карпат за останнє десятиріччя поширилося в усіх типах лісу, де ростуть ялинники, а за охопленою площею - характер катастрофічного явища 3 антропогенних і природних причин (Маuer \& Palátová, 2010; Janda et al., 2014; FAO, 2016; Shparyk, 2014). Основним наслідком такого інтенсивного всихання ялини є зміна породного складу та головної породи в лісах Українських Карпат - місце ялини в деревостанах природним шляхом займає переважно бук лісовий (Fagus sylvatica L.), хоча в дубових типах лісу це може бути граб звичайний (Carpinus betulus L.), липа дрібнолиста (Tilia cordata Mill.) чи клени, а в ялицевих - ялиця біла (Abies alba Mill.). Тобто в лісівничому плані загрози втрати лісового фонду немає, хоча зрозуміло, що цінність ялинових та букових лісів для національної економіки різна (Shparyk, 2019).

Розрахунок економічних, екологічних (біорізноманіття, депонування вуглецю, продукування кисню) та соціальних (зайнятість місцевого населення, рекреаційна ємність) наслідків всихання ялинників регіону дає підстави зазначити про наявність як негативних, так і позитивних моментів у цьому процесі, які можуть істотно різнитися за типами лісу (Shparyk, 2017; UkrRIMF, 2017; Shparyk, 2018). Тому для лісового господарства актуальне прогнозування площі ялинників, які залишаться, і особливо - запасів ялинової деревини

в найближчій перспективі.

Методика дослідження. Оскільки прогнозування це оцінка (розрахунок) майбутнього стану предмету прогнозування на основі аналізу його попередньої динаміки, то для розрахунків змін ялинників Українських Карпат у найближчі роки було використано інформацію про їхню динаміку на постійних дослідних об'єктах регіону за типами лісу (Lavryk, 2010; Bokoch et al., 2014; Kansanen et al., 2016). Об'єктами дослідження були понад 20 постійний пробних площ УкрНДІгірліс, лісівничий і таксаційних опис яких докладно представлено в попередніх публікаціях (Shparyk, 2014; Shparyk, 2017; UkrRIMF, 2017). Інтенсивність всихання ялинників визначали на дослідних об'єктах у частках зменшення запасу деревини за роками впродовж періоду досліджень.

Для прогнозування змін санітарного стану ялинників прийнято за базове положення, яке $\epsilon$ результатом попередніх досліджень, - інтенсивність всихання ялинників, що переважно визначаємо за трьома показниками лісової ділянки в межах одного типу лісу: група віку, повнота деревостану, частка ялини в породному складі. Для розрахунку прогнозних значень змін ялинових лісів використали функцію екстраполяції існуючих тенденцій цих змін. Значною перевагою такого методу $\epsilon$ те, що існуючі закономірності динаміки лісів спостерігаємо на конкретних дослідних об'єктах, властиві са-

\section{Інформація про авторів:}

Шпарик Юрій Степанович, д-р с.-г. наук, ст. наук. співробітник, головний науковий співробітник лабораторії екології та захисту лісу. Email: yuriy.shparyk@gmail.com; https://orcid.org/0000-0001-8047-6356

Цитування за ДСту: Шпарик Ю. С. Емпіричні підходи до прогнозування площі та запасу ялинових (Picea abies (L.) Karst.) лісів Українських Карпат. Науковий вісник НЛтУ України. 2019, т. 29, № 3. С. 18-22.

Citation APA: Shparyk, Yu. S. (2019). Empirical approaches to forecasting area and wood volume of spruce (Picea abies (L.) Karst.) forests in the Ukrainian Carpathians. Scientific Bulletin of UNFU, 29(3), 18-22. https://doi.org/10.15421/40290303 
ме для цих типів лісу. Також прийнято за базове припущення, що кліматичні показники останніх років будуть мати сталі тенденції. Інтенсивність всихання ялини за трьома показниками прогнозування розраховували за формулою.

$$
I B Я=I B Я_{1} \cdot I B Я_{2} \cdot I B Я_{3},
$$

де: $I B Я$ - інтенсивність всихання ялини за показниками прогнозування; $I B Я_{1}-$ інтенсивність всихання ялини для цієї групи віку; $I B Я_{2}-$ інтенсивність всихання ялини для цієї повноти; $I B Я_{3}$ - інтенсивність всихання ялини для цієї частки ялини.

Результати дослідження. Достовірні результати інтенсивності всихання ялинників за типами лісу були визначені тільки для тих типів лісу, де було не менше 3-х дослідних об'єктів: в умовах вологої чистої сусмеречини середня інтенсивність всихання становила $3 \%$ за рік; вологої буково-ялицевої сусмеречини - $1 \%$ за рік; вологої буково-смерекової суяличини - $2 \%$ за рік. Саме в цих типах лісу площа ялинників у регіоні Українських Карпат найбільша. Встановлені на дослідних об'єктах частки всихання найбільш характерні для середніх значень цих показників - це середньовікові та середньоповнотні ліси з часткою ялини в породному складі на рівні 6-7 одиниць. За групами віку інтенсивність всихання ялинників знижується завдяки зменшенню їх віку і відповідно зростає - внаслідок збільшення віку (від середньовікових лісів). За часткою ялини закономірність всихання ялинників подібна до віку - інтенсивність всихання ялинників знижується завдяки зменшенню частки ялини і відповідно зростає - внаслідок збільшення ії частки (від частки в 6-7 одиниць). За повнотою деревостанів закономірність всихання ялинників зворотна - інтенсивність всихання ялинників зростає внаслідок зменшення повноти і відповідно знижується - завдяки ії збільшенню (від середньої повноти).

Для екстраполяції інтенсивності всихання ялинників на інші (не представлені на дослідних об'єктах) типи лісу використано такі встановлені закономірності: завдяки збільшенню вологості та родючості типів лісу інтенсивність всихання ялини зменшується, а внаслідок зменшення вологості та родючості- збільшується; у змішаних (не однопородних) типах лісу інтенсивність всихання ялини менша за чисті (однопородні) типи лісу; в не смерекових типах лісу інтенсивність всихання ялини більша, ніж у смерекових, а в типах лісу поза межами природного ареалу ялини - інтенсивність всихання ще вища. Перелік типів лісу, в яких ростуть ялинники, взято з матеріалів лісовпорядкування. Розраховану за цими підходами інтенсивність всихання ялинників (частки від запасу) у смерекових типах лісу наведено в табл. 1. Отримані результати свідчать, що зміна інтенсивності всихання ялини в смерекових типах лісу відбувається від 0,1 до $6 \%$ за запасом деревини в рік. Закономірно найбільша інтенсивність всихання ялини $\epsilon$ в суборових типах лісу, в перестійних, низькоповнотних та чистих ялинових деревостанах.

Аналогічні дані для не букових типів лісу свідчить про значно вищу інтенсивність всихання тут ялинників, порівняно зі смерековими типами лісу (зміна відбувається від 0,1 вже до 9\%), і особливо це стосується чистих ялинників в умовах свіжої чистої субучини (табл. 2). Зміна інтенсивності всихання ялини в інших (ялицевих, дубових та вільхових) типах лісу відбувається від 0,1 до $10 \%$ за запасом деревини в рік, тобто теж вища, ніж у смерекових типах лісу, і особливо це стосується чистих ялинників в умовах вологих букової та грабової судібров (табл. 3).

Табл. 1. Інтенсивність всихання ялинників у смерекових типах лісу

\begin{tabular}{|c|c|c|c|c|c|c|c|c|}
\hline \multirow{2}{*}{ Показник лісів } & \multicolumn{8}{|c|}{ За типами лісу, $V, \% /$ рік } \\
\hline & $\mathrm{B}_{3}-\mathrm{CM}_{\mathrm{M}}$ & $\mathrm{B}_{3}-\mathrm{K} \mathrm{CM}_{\mathrm{M}}$ & $\mathrm{C}_{3}$-бкСм & $\mathrm{C}_{3}-\mathrm{CM}_{\mathrm{M}}$ & $\mathrm{C}_{3}$-бк-яцСм & $\mathrm{C}_{3}$-яцСМ & $\mathrm{C}_{4}-\mathrm{CM}_{\mathrm{M}}$ & $\mathrm{D}_{3}$-бк-яцСм \\
\hline \multicolumn{9}{|c|}{ За групами віку } \\
\hline Молодняки I класу віку & 1 & 0,5 & 1 & 1 & 0,5 & 1 & 0,1 & 0,5 \\
\hline Молодняки II класу віку & 2 & 1 & 2 & 2 & 1 & 2 & 0,5 & 0,5 \\
\hline Середньовікові & 3 & 2 & 3 & 3 & 2 & 3 & 1 & 1 \\
\hline Пристигаючі & 4 & 3 & 3 & 4 & 3 & 3 & 2 & 1 \\
\hline Стиглі & 5 & 4 & 4 & 5 & 4 & 4 & 3 & 2 \\
\hline Перестиглі & 6 & 5 & 5 & 6 & 5 & 5 & 4 & 2 \\
\hline \multicolumn{9}{|c|}{ За повнотою } \\
\hline Низька повнота $(0,01-0,40)$ & 5 & 4 & 5 & 5 & 4 & 5 & 4 & 2 \\
\hline Середня повнота $(0,41-0,80)$ & 3 & 2 & 3 & 3 & 2 & 3 & 2 & 1 \\
\hline Висока повнота $(0,81$ і вище) & 1 & 1 & 1 & 1 & 0,5 & 1 & 0,5 & 0,5 \\
\hline \multicolumn{9}{|c|}{ За часткою ялини (одиниць породного складу) } \\
\hline 10 & 5 & 5 & 5 & 5 & 4 & 5 & 4 & 2 \\
\hline 9 & 4 & 4 & 4 & 4 & 3 & 4 & 3 & 2 \\
\hline 8 & 4 & 4 & 3 & 4 & 3 & 3 & 3 & 1 \\
\hline 7 & 3 & 3 & 3 & 3 & 2 & 3 & 2 & 1 \\
\hline 6 & 3 & 3 & 2 & 3 & 2 & 2 & 2 & 0,5 \\
\hline 5 & 2 & 2 & 2 & 2 & 1 & 2 & 1 & 0,5 \\
\hline 4 & 2 & 2 & 1 & 2 & 1 & 1 & 1 & 0,2 \\
\hline 3 & 1 & 1 & 1 & 1 & 0,5 & 1 & 0,5 & 0,2 \\
\hline 2 & 1 & 1 & 0,5 & 1 & 0,5 & 0,5 & 0,5 & 0,1 \\
\hline 1 & 0,5 & 0,5 & 0,5 & 0,5 & 0,1 & 0,5 & 0,1 & 0,1 \\
\hline+ & 0,1 & 0,1 & 0,1 & 0,1 & 0,1 & 0,1 & 0,1 & 0,1 \\
\hline
\end{tabular}

Табл. 2. Інтенсивність всихання ялинників у букових типах лісу

\begin{tabular}{|c|c|c|c|c|c|c|c|c|}
\hline \multirow{2}{*}{ Показник лісів } & \multicolumn{8}{|c|}{ За типами лісу, $V, \% /$ рік } \\
\hline & $\mathrm{C}_{2}$-Бк & $\mathrm{C}_{3}-$-Бк & $\mathrm{C}_{3}$-Г-дБк & $\mathrm{C}_{3}$-см-яцБК & $\mathrm{C}_{3}$-явБк & $\mathrm{C}_{3}$-яцБк & $\mathrm{D}_{3}$-Г-дБк & $\mathrm{D}_{3}$-см-яцБк \\
\hline \multirow{2}{*}{\multicolumn{9}{|c|}{ За групами віку }} \\
\hline & & & & & & & & \\
\hline Молодняки I класу віку & 2 & 1 & 1 & 1 & 1 & 0,5 & 1 & 0,5 \\
\hline Молодняки II класу віку & 3 & 2 & 2 & 2 & 2 & 1 & 2 & 1 \\
\hline Середньовікові & 4 & 3 & 3 & 3 & 3 & 2 & 2 & 2 \\
\hline
\end{tabular}




\begin{tabular}{|c|c|c|c|c|c|c|c|c|}
\hline 1 & 2 & 3 & 4 & 5 & 6 & 7 & 8 & 9 \\
\hline Пристигаючі & 5 & 4 & 4 & 4 & 4 & 3 & 3 & 2 \\
\hline Стиглі & 6 & 5 & 5 & 5 & 5 & 4 & 3 & 3 \\
\hline Перестиглі & 7 & 5 & 6 & 6 & 6 & 5 & 4 & 3 \\
\hline \multicolumn{9}{|c|}{ За повнотою } \\
\hline Низька повнота $(0,01-0,40)$ & 7 & 5 & 5 & 4 & 5 & 5 & 5 & 3 \\
\hline Середня повнота $(0,41-0,80)$ & 5 & 3 & 3 & 3 & 3 & 3 & 3 & 2 \\
\hline Висока повнота (0,81 і вище) & 3 & 1 & 2 & 2 & 2 & 1 & 2 & 1 \\
\hline \multicolumn{9}{|c|}{ За часткою ялини (одиниць породного складу) } \\
\hline 10 & 9 & 6 & 6 & 6 & 6 & 6 & 5 & 4 \\
\hline 9 & 8 & 7 & 5 & 5 & 6 & 5 & 5 & 3 \\
\hline 8 & 7 & 6 & 5 & 4 & 5 & 5 & 4 & 2 \\
\hline 7 & 6 & 5 & 4 & 3 & 5 & 4 & 4 & 2 \\
\hline 6 & 6 & 4 & 4 & 3 & 4 & 3 & 3 & 1 \\
\hline 5 & 5 & 4 & 3 & 2 & 4 & 3 & 3 & 1 \\
\hline 4 & 5 & 3 & 3 & 2 & 3 & 2 & 2 & 0,5 \\
\hline 3 & 4 & 3 & 2 & 1 & 3 & 2 & 2 & 0,5 \\
\hline 2 & 4 & 2 & 2 & 1 & 2 & 1 & 1 & 0,2 \\
\hline 1 & 3 & 2 & 1 & 0,5 & 1 & 1 & 0,5 & 0,2 \\
\hline+ & 3 & 1 & 1 & 0,1 & 0,5 & 0,5 & 0,2 & 0,1 \\
\hline
\end{tabular}

Табл. 3. Інтенсивність всихання ялинників в інших типах лісу

Показник лісів

\begin{tabular}{|c|c|c|c|c|c|c|c|c|c|c|}
\hline \multirow{2}{*}{ Показник лісів } & \multicolumn{10}{|c|}{ За типами лісу, V, \%/рік } \\
\hline & $\mathrm{C}_{3}$-бкЯц & $\mathrm{C}_{3}-б \kappa-\mathrm{-смЯц}$ & $\mathrm{C}_{3}-д Я_{ц}$ & $\mathrm{D}_{3}$-бк-смЯц & $\mathrm{B}_{3}$-Влз & $\mathrm{C}_{4}$-Влс & $\mathrm{C}_{3}$-бкД & $\mathrm{C}_{3}-\Gamma Д$ & $\mathrm{C}_{3}$-яцД & $\mathrm{D}_{3}$-г-бкД \\
\hline \multicolumn{11}{|c|}{ За групами віку } \\
\hline Молодняки I класу віку & 0,5 & 0,5 & 1 & 0,1 & 1 & 1 & 3 & 3 & 1 & 2 \\
\hline Молодняки II класу віку & 1 & 1 & 2 & 0,5 & 2 & 2 & 4 & 5 & 2 & 4 \\
\hline Середньовікові & 2 & 2 & 3 & 1 & 4 & 3 & 5 & 7 & 4 & 6 \\
\hline Пристигаючі & 3 & 2 & 4 & 1 & 5 & 3 & 6 & 8 & 4 & 7 \\
\hline Стиглі & 4 & 3 & 5 & 2 & 6 & 4 & 7 & 9 & 5 & 8 \\
\hline Перестиглі & 5 & 4 & 6 & 3 & 7 & 4 & 8 & 10 & 6 & 9 \\
\hline \multicolumn{11}{|c|}{ За повнотою } \\
\hline Низька повнота $(0,01-0,40)$ & 4 & 4 & 5 & 3 & 6 & 4 & 6 & 9 & 5 & 8 \\
\hline Середня повнота $(0,41-0,80)$ & 3 & 2 & 3 & 1 & 4 & 3 & 4 & 7 & 4 & 6 \\
\hline Висока повнота $(0,81$ і вище) & 2 & 1 & 1 & 1 & 3 & 2 & 2 & 5 & 3 & 4 \\
\hline \multicolumn{11}{|c|}{ За часткою ялини (одиниць породного складу) } \\
\hline 10 & 6 & 5 & 5 & 4 & \begin{tabular}{|l|l|}
7 \\
\end{tabular} & 5 & 10 & 10 & 6 & 9 \\
\hline 9 & 5 & 4 & 4 & 3 & 6 & 4 & 8 & 9 & 5 & 8 \\
\hline 8 & 4 & 3 & 4 & 2 & 5 & 4 & 6 & 8 & 5 & 7 \\
\hline 7 & 3 & 2 & 3 & 1 & 4 & 3 & 5 & 7 & 4 & 6 \\
\hline 6 & 3 & 2 & 3 & 1 & 4 & 3 & 5 & 7 & 4 & 6 \\
\hline 5 & 2 & 1 & 2 & 0,5 & 3 & 2 & 4 & 6 & 3 & 5 \\
\hline 4 & 2 & 1 & 2 & 0,5 & 3 & 2 & 4 & 5 & 3 & 5 \\
\hline 3 & 1 & 0,5 & 1 & 0,2 & 2 & 1 & 3 & 4 & 2 & 4 \\
\hline 2 & 0,5 & 0,5 & 1 & 0,2 & 2 & 1 & 3 & 3 & 2 & 3 \\
\hline 1 & 0,2 & 0,2 & 0,5 & 0,1 & 1 & 0,5 & 2 & 2 & 1 & 2 \\
\hline+ & 0,1 & 0,1 & 0,1 & 0,1 & 0,5 & 0,5 & 1 & 1 & 1 & 1 \\
\hline
\end{tabular}

Наступним етапом прогнозу був збір інформації за підприємствами регіону Українських Карпат щодо площі та запасу деревини ялинників у межах показників прогнозування (група віку, повнота деревостану, частка ялини в породному складі) за типами лісу. Метод було апробовано для ялинників ДП "Надвірнянське лісове господарство" в умовах найбільш поширеного на підприємстві типі лісу (волога буково-ялицева сусмеречина). Після розрахунку запасів ялинників прийнято твердження, що щорічний приріст їх деревини забирався 3 деревостанів під час вживання господарських заходів. Висновки $з$ проведених розрахунків свідчать про різке зменшення запасів ялинників внаслідок всихання - за 20 років від 2,29 млн м ${ }^{3}$ до 390 тис. м $^{3}$, або більше, як у 5 разів (рисунок).

При цьому площа ялинників зменшиться не так швидко - від 6,5 до 5,3 тис. га, або на 1,2 тис. га (на $18,5 \%$ ). Особливо відчутним прогнозуємо зменшення запасів у середньовікових ялинниках, які всихають найбільш масово, а саме:

- в ялинових молодняках запаси зменшилися від 7,68 до 2,24 тис. м $^{3}$, або становили $29 \%$ від початкових;

- у середньовікових ялинниках запаси зменшилися від 1,39 до 0,21 млн м ${ }^{3}$, або становили $15 \%$ від початкових;
- у стиглих ялинниках запаси зменшилися від 337 до 77 тис. $\mathrm{m}^{3}$, або становили $23 \%$ від початкових.

Результати прогнозування всихання ялинників ДП "Надвірнянське лісове господарство" свідчать про можливу втрату ялинових лісів в умовах вологої буковоялицевої сусмеречини на площі 1,2 тис. га та зменшення запасів ялинової деревини на 1,9 млн м ${ }^{3}$, або майже на $90 \%$.

Обговорення результатів дослідження. Наслідки масового всихання ялинових лісів Українських Карпат, без сумніву, будуть мати визначальне значення для лісового господарства регіону в площині переорієнтації деревопереробних підприємств з лісопиляння ялинової деревини на переробку букової деревини. Тому зараз необхідно вживати заходи для поступової зміни структури виробничих фондів таких підприємств. Важливим моментом тут $\epsilon$ розуміння динаміки всихання ялинників за різними типами лісу і типами деревостанів, бо якщо в умовах вологої буково-ялицевої сусмеречини прогнозуємо втрату майже 90 \% ялинової деревини, то в умовах вологої чистої сусмеречини ці втрати не будуть перевищувати 50 \%. Це означає, що різні підприємства лісового господарства будуть втрачати ялинову деревину з різною інтенсивністю залежно від лісо- 
типологічної структури їх ялинників. Запропонований у цій публікації метод прогнозування змін площ та запасів унаслідок всихання ялинових лісів якраз і дасть змогу оцінити ці втрати для кожного підприємства залежно від типів лісу і типів деревостанів їх ялинників.

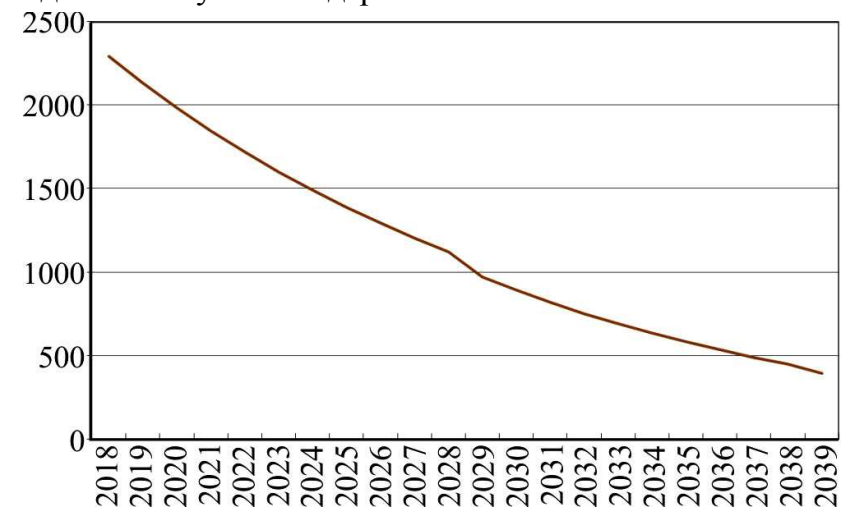

Рисунок. Прогнозні зміни запасів ялини в умовах вологої буковоялицевої сусмеречини ДП "Надвірнянське лісове господарство"

Не менш важливим питанням у цьому контексті $є$ заходи з відновлення площі ялинових лісів у регіоні, бо значення ялинової деревини для господарства регіону важко переоцінити - це основні будівельні пиломатеріали. Проведені дослідження свідчать про перспективні для створення ялинників типи лісу - ті, в яких інтенсивність всихання найменша. Передусім це грудові смерекові типи лісу (волога і сира буково-ялицеві смеречини та волога і сира ялицеві смеречини) і грудові ялицеві та букові типи лісу (волога і сира буково-смерекові яличини та волога і сира смереково-ялицеві бучини). Особливо важливим для успішного росту ялини є достатня іiі частка та правильне розташування посадкового матеріалу для зменшення конкуренції з буком. Представлені розрахунки свідчать, що за частки ялини в породному складі 30-40 \% інтенсивність іiі всихання не перевищує $1 \%$, тобто є незначною. 3 урахуванням приживлюваності посадкового матеріалу ялини 80-90 \% (Brodovych, 2013), пропонуємо в складі лісових культур цих типів лісу проектувати частку ялини 40-50 \%.

Також не варто відмовлятися від формування ялинників у класичних смерекових типах лісу (волога і сира чисті сусмеречини), але підходи тут дещо інші. Пропонуємо збільшити густоту лісових культур у цих типах лісу до мінімуму в 6,5 тис. шт./га, що дасть змогу збільшити повноту ялинників і відповідно зменшити інтенсивність їх всихання. Склад лісових культур потрібно формувати не з чистої ялини, - а за участю ялиці, горобини та інших порід на рівні 10-20\%. Окремо варто зазначити про недоцільність проведення доглядових рубань в таких ялинових молодняках, щоб не зменшувати повноту - тільки за нагальної потреби (загроза зміни головної породи).

Необхідно відновити роботи зі створення плантаційних культур ялини в тих типах лісу, де вона інтенсивно всихає (дубових, вільхових, букових), щоб в 4050 років її вирубувати і формувати корінні ліси.

Висновки. Розраховані зміни інтенсивності втрати ялинової деревини внаслідок всихання на дослідних об'єктах за типами лісу Українських Карпат відбуваються від 0,1 до $10 \%$ у рік. Встановлено такі закономірності всихання ялинників: завдяки збільшенню вологості та родючості типів лісу інтенсивність всихання ялини зменшується; у не смерекових типах лісу інтен- сивність всихання ялини більша, ніж у смерекових; у змішаних (не однопородних) типах лісу інтенсивність всихання ялини менша за чисті (однопородні) типи лісу; в типах лісу поза межами природного ареалу ялини інтенсивність її всихання найвища.

Прогноз всихання ялинників ДП "Надвірнянське лісове господарство" свідчить про можливу втрату в умовах вологої буково-ялицевої сусмеречини в наступних 20 років ялинників на площі 1,2 тис. га (на 18\%) та зменшення запасів ялинової деревини на 1,9 млн м³ , або майже на $90 \%$.

Для відновлення площі ялинових лісів підготовлено пропозиції за трьома групами типу лісу: в змішаних грудових типах лісу - довести частку ялини в породному складі лісових культур до 40-50 \%, а схемою змішання - запобігти її пригніченню буком; у чистих смерекових - густоту лісових культур довести мінімум до 6,5 тис. шт./га і відмовитися від доглядових рубань в молодняках; в інших типах лісу - створювати плантаційні культури.

\section{Перелік використаних джерел}

Bokoch, V. V., Lakyda, P. I., Vasylyshyn, R. D., \& Terentev, A. Y. (2012). Modeling of parameters of phytomass components of Carpathian NNP forest stands. Ser. Forestry. Scientific Bulletin of NAU, 171(2), 18-25. Kyiv: Publishing NAU. [In Ukrainian].

Brodovych, R. I., Gudyma, V. M., Brodovych, Y. R., \& Katsukyak, Y. D. (2013). Natural regeneration of the main forest species of the Carpathian region and ways of its intensification. Scientific Bulletin of UNFU, 23(5), 162-168. [In Ukrainian].

FAO. (2016). Global forest resources assessment 2015. How are the world's forests changing? Second edition. Rome, FAO. Retrived from: http://www.fao.org/3/a-i4793e.pdf.

Janda, P., Svoboda, M., Bače, R., Cada, V., Lynn, J., \& Peck, E. (2014). Three hundred years of spatio-temporal development in a primary mountain Norway spruce stand in the Bohemian Forest, central Europe. Forest Ecology and Management, 330, 304-311.

Kansanen, K., Vauhkonen, J., Lähivaara, T., \& Mehtätalo, L. (2016). Stand density estimators based on individual tree detection and stochastic geometry. Canadian Journal of Forest Research. https://doi.org/10.1139/cifr.

Lavryk, V. I. (2010). Modeling and forecasting the state of the environment. Kyiv: Akademiya, 400 p. [In Ukrainian].

Mauer, O., \& Palátová, E. (2010). Decline of Norway spruce in the Krkonoše Mts. Journal of Forest Science, 56, 361-372.

Shparyk, Y. S. (2014). Form diversity and health conditions of Norway spruce (Picea abies (L.) Karst.) in the main forest types of the Ukrainian Carpathians. Forestry \& Agroforestmelioration, 125, 8796. [In Ukrainian].

Shparyk, Y. S. (2017). Economic results of spruce forests' decline in the Ukrainian Carpathians. Scientific Works of the Ukrainian Forestry Academy of Sciences, 15, 129-139. [In Ukrainian].

Shparyk, Y. S. (2018). Ecological results of spruce forests' decline in the Ukrainian Carpathians. The main problems and tendencies of the further development of forestry in the Ukrainian Carpathians, 140-146. Ivano-Frankivsk: HAIP. [In Ukrainian].

Shparyk, Y. S. (2019). Causes and consequences of a mass decline of spruce forests in the Carpathians, forecast of their area dynamics and proposals for the maintenance of nature protection in them. Retrived from: http://ukrrimf.org.ua/wp-content/uploads/2019/02/ vsyh-yalyny-PZF-Kyyiv-270219.pdf. [In Ukrainian].

UkrRIMF. (2017). To develop a forecast of health conditions and to propose measures on the use of spruce forests of Carpathians taking into account the ecological, economic and social approaches. Scientific report of manager Shparyk, Y. S., № DR 0115U001859. IvanoFrankivsk: UkrRIMF, 150 p. [In Ukrainian]. 


\section{EMPIRICAL APPROACHES TO FORECASTING AREA AND WOOD VOLUME OF SPRUCE (PICEA ABIES (L.) KARST.) FORESTS IN THE UKRAINIAN CARPATHIANS}

Stationary investigations of the spruce (Picea abies (L.) Karst.) forests decline in the Ukrainian Carpathians at 22 permanent research sites made it possible to estimate the intensity of their deterioration for the main forest types in which spruce forests grow. This publication proposes a method for predicting the area of spruce forests in the region and volumes of spruce wood according to percentages of the wood volume losses. For the development of the forecast, we took as the basic an identified position that the intensity of the spruce forests decline is determined by such indicators of the forest stands within one type of forest as age group, basal area, and the proportion of spruce in the species composition. Extrapolation function of the existing tendencies of the spruce forests decline used for the calculation for non-surveyed forest types and types of tree stands. These tendencies were as follow: with an increase of the forest types humidity the intensity of the spruce forests decline decreases; with an increase of the forest types fertility the intensity of the spruce forests decline decreases; in non-spruce forest types, the intensity of the spruce forests decline was more than in spruce ones; in mixed forest types, the intensity of the spruce forests decline was less than in pure ones; in forest types outside the natural area of spruce, the intensity of the spruce forests decline was the highest; spruce forests decline begins in middleaged forests and with age its intensity increases; with basal area decreasing, the intensity of the spruce forests decline increases; with decreasing of the proportion of spruce in the species composition, the intensity of the spruce forests decline decreases. The forecast of the spruce forests decline for the state-owned enterprise "Nadvirnyanske Forestry" in the conditions of the wet common beech silver fir - Norway spruce fairly fertile forest type gave a loss of 18 percent of the spruce forests area and almost 90 percent of the spruce wood volume in the next 20 years. The authors have prepared proposals for increasing of the regional spruce forests area according to forest types: in mixed fertile forest types - increasing the proportion of spruce in forest cultures to $40-50 \%$; in pure fairly fertile forest types - increasing the density of spruce in forest cultures to more than 6.5 ths./ha; in other forest types - planting of the spruce forest plantations.

Keywords: Norway spruce (Picea abies (L.) Karst.); forest decline; type of forest; age group; basal area; species composition; forest culture; tending felling. 